\title{
Classification of Wave Energy Converters
}

\author{
M Dolores Esteban*, José-Santos López-Gutiérrez and Vicente Negro \\ Universidad Politécnica de Madrid, Spain
}

Submission: July 05, 2017; Published: August 04, 2017

*Corresponding author: M. Dolores Esteban, Universidad Politécnica de Madrid, Spain, Email: mariadolores.esteban@upm.es

\begin{abstract}
Wave is one of the main sources of renewable energy in the sea, due to its great potential to be harnessed. Currently, the technology is not mature enough to be developed in an industrial way, and its levelized cost of energy (LCOE) is still too high. One of the key points for the development of this energy is the technological progress of the wave energy converters (WEC), in which great efforts are being focused. In fact, there are numerous types of WECs in different stages of development. Given the differences between them, there are several classifications based on several aspects such as the location in relation to the distance to the coast and the bathymetry, the position relative to the sea level, the size and orientation, and the energy capture principle.
\end{abstract}

Keywords: Wave energy; Marine energy; Renewable energy; WEC

\section{Introduction}

Global wave energy potential is around 500 gig watts (GW), considering $40 \%$ of conversion efficiency [1,2], making it one of the main marine renewable energy sources [3-8]. Although different investigations have been carried out since the $19^{\text {th }}$ century, it has not been until the 1970s that much effort has been invested [9]. In spite of this, the technology of the exploitation of wave energy has not yet reached the maturity enough for its development in industrial and commercial scale [10]. To achieve an adequate development of wave energy, one of the points to be focused on is the technology to be used in the wave energy converters (WEC). Now a day, there are numerous types of WECs [11] in development, having important differences between them. Therefore, there are several classifications of WECs that will be cited throughout this document.

\section{Existing classification of Wave Energy Converters}

Due to the existence of numerous and different WECs [12], there are several classification according to the following criteria:

a. location of the device in relation to the bathymetry and the distance to the coast,

b. position of the device related to the sea level,

c. size and orientation of the device, and

d. Energy captures principle [2].
Regarding the first of these classification, we can distinguish between onshore, near shore and offshore facilities $[13,14]$.The onshore term refers to one located on the coast, usually taking advantage either of an existing or new structure to be built, such as a breakwater. The near shore term refers to shallow water with depths not exceeding 50 metres, located relatively close to the shoreline. Offshore means waters deeper than 50 metres, in more remote areas of the coast than near shore facilities. Previous definitions of shallow and deep water must be understand only for wave farms, and should not be confused with the ones used in maritime engineering for wave theories.

Regarding the second of the classifications mentioned, we can distinguish between emerged, semi-submerged and submerged. Furthermore, depending on the type of support structure, they can be bottom-standing or floating with mooring system. Regarding the third of these classifications, there are point absorber, attenuator, and terminator WEC. Point absorber devices generally have small dimensions compared to the wavelength, absorbing wave energy in any direction. Attenuator devices have their main axis or dimension parallel to incident wave direction. Terminator devices have their main axis perpendicular to the incident wave direction.

The fourth of the classifications distinguishes between oscillating water column (OWC), Archimedes effect, and 
buoyant body with fixed reference, buoyant body with mobile reference, overtopping, and impact (Figure 1). Oscillating water columns (OWC) use the change of the level of water due to waves inside a chamber to move the air to active an air turbine. Archimedes effect takes into account the change in the pressure over the devices caused by waves. Buoyant bodies with fixed and mobile reference take advantage of the relative movement between two parts of the device. Overtopping wave devices exploit the water passing over the freeboard of the structure. Impact devices are moved due to the action of waves.

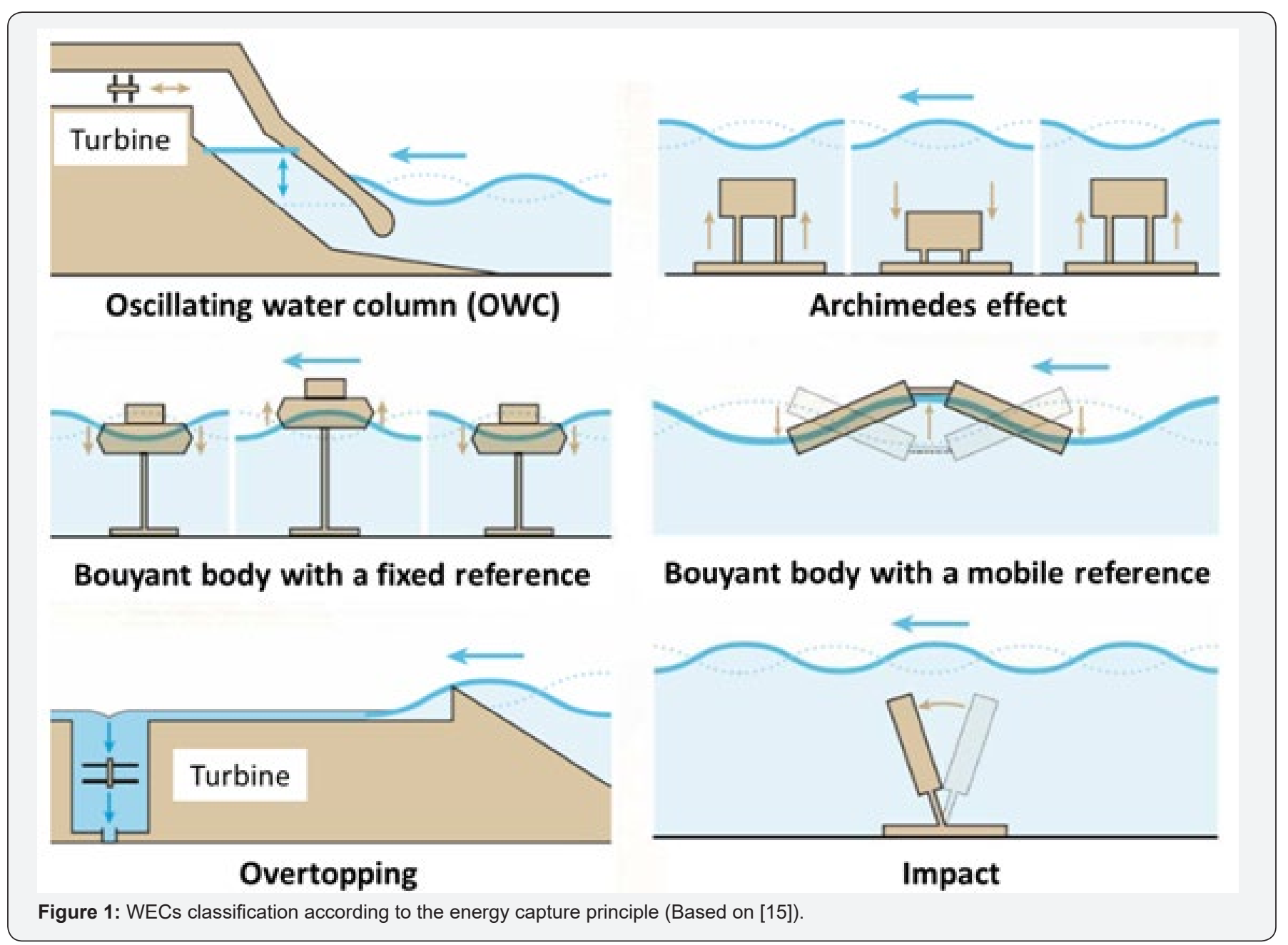

There are other classifications taking into account all the previous mentioned criteria and other ones, for instance, EMEC one [16] distinguishes between
i. Attenuator
ii. Point absorber
iii. Oscillating wave surge converter
iv. Oscillating water column
v. Overtopping/terminator device
vi. submerged pressure differential
vii. Bulge wave
viii. Rotating mass

ix. Others (Figure 2) 


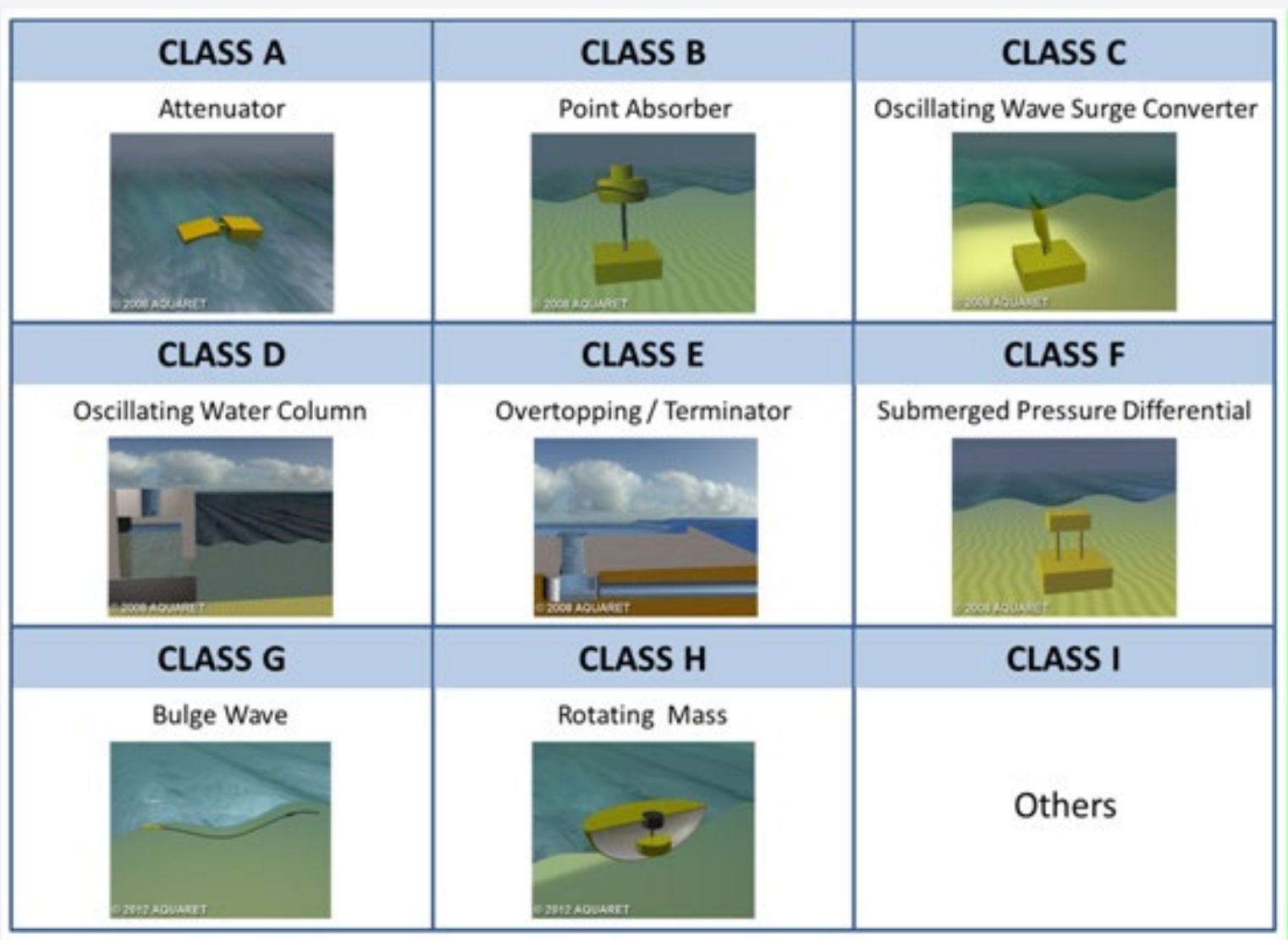

Figure 2: WECs classification by EMEC: A) attenuator, B) point absorber, C) oscillating wave surge converter, D) oscillating water column, E) overtopping/terminator device, F) submerged pressure differential, G) bulge wave, H) rotating mass and I) others (based on [16]).

Different WECs have been developed, and the distribution between the types according to the EMEC classification is the following one: $40 \%$ are point absorber ones (B), $23 \%$ are attenuator ones (A), 19\% are oscillating wave surge ones (C), $7 \%$ are oscillating water column ones (D), $7 \%$ rotating mass ones $(\mathrm{H}), 1 \%$ are bulge wave ones $(\mathrm{G})$ and $3 \%$ are overtopping ones (E) and others (I) [16].

Based on the analysis the most known existing WECs, it can be given some examples for the different types following the EMEC classification: Pelamis in Orkney for A) Attenuator; Santoña Power Buoy for B) Point Absorber; Oyster in Orkney for C) Oscillating Wave Surge; Mutriku Breakwater for D) Oscillating Water Column; Wave Dragon North Sea Demonstrator for E) Overtopping / Terminator; Archimedes Wave Swing for F) Submerged Pressure Differential; Anaconda for G) Bulge Wave, and Wello Penguin for H) Rotating Mass.

\section{Conclusion}

The potential for generating electricity from wave energy is considerable. To achieve a commercial development of WECs, it will be necessary a lot of effort in time and money in research projects. Up to this moment, important resources have been allocated for it, but the dispersion on WEC types is significant.
A right allocation of the resources looking for synergies is advisable. There are different classifications of WECs. The most known ones are those based on the location of the relative to the coast, the position of the device related to the sea level, the size and orientation of the device, and the energy capture principle. Furthermore, EMEC wave device classification distinguishes between attenuator, point absorber, oscillating wave surge converter, oscillating water column, overtopping / terminator device, submerged pressure differential, bulge wave, rotating mass and others.

\section{References}

1. Hayward J, Osman P (2011) The potential of wave energy. CSIRO technical document, p. 18.

2. Irena (2014) Wave Energy: Technology Brief. International Renewable Energy Agency technical report, p. 28.

3. Bahaj AS (2011) Generating electricity from the oceans. J Renew and Sustain Energy Reviews 15(7): 3399-3416.

4. Esteban MD, Diez JJ, López-Gutiérrez JS, Negro V (2011) Why Offshore Wind Energy? J Renew Energy 36: 444-450.

5. Carballo R, Iglesias G (2012) A methodology to determine the power performance of wave energy converters at a particular coastal location. J Energy Convers Manag 61: 8-18. 
6. Pinson P, Reikard G, Bidlot JR (2012) Probabilistic forecasting of the wave energy flux. J Applied Energy 93: 364-370.

7. Fadaeenejad M, Shamsipou R, Rokni SD, Gomes C (2014) New approaches in harnessing wave energy: With special attention to small islands. J Renew and Sustain Energy Reviews 29: 345-354.

8. Uihlein A, Magagna D (2016) Wave and tidal current energy -A review of the current state of research beyond technology. J Renew and Sustain Energy Reviews 58: 1070-1081.

9. Magagna D, Uihlein A (2014) JRC Ocean Energy Status Report. Technology, market and economic aspects of ocean energy in Europe. JCR Science and Policy Reports 2015: 74.

10. López I, Andreu J, Ceballos S, Martínez de Alegría I, Kortabarria I, et al. (2013) Review of wave energy technologies and the necessary powerequipment. J Renew and Sustain Energy Reviews 27: 413-434.
11. Ilyas A, Kashif SAR, Saqib MA, Asa MM (2014) Wave electrical energy systems: Implementation, challenges and environmental issues. J Renew and Sustain Energy Reviews 40: 260-268.

12. Falnes J (2007) A review of wave-energy extraction. J Marine Structures 20(4): 185-201.

13. Cruz J (2008) Ocean Wave Energy: current status and future perspectives. Springer, Heidelberg , p. 423.

14. Falcão AFO (2010) Wave Energy Utilization: A Review of the technologies. J Renew and Sustain Energy Reviews 14(3): 899-918.

15. Ibáñez P (2008) Energía de las olas: situación y futuro. Xornada sobre Enerxía que Vén do Mar, Coruña.

16. www.emec.org.uk

\section{Your next submission with Juniper Publishers} will reach you the below assets

- Quality Editorial service

- Swift Peer Review

- Reprints availability

- E-prints Service

- Manuscript Podcast for convenient understanding

- Global attainment for your research

- Manuscript accessibility in different formats

( Pdf, E-pub, Full Text, Audio)

- Unceasing customer service

Track the below URL for one-step submission https://juniperpublishers.com/online-submission.php 